\title{
An Analysis of the Impact of Culture on Pedagogy in the Tribal Area of Dera Ghazi Khan (Pakistan)
}

\author{
Muhammad Tanveer Afzal, Khalida Nasreen* \\ T.ED Department, AIOU, Pakistan \\ *Corresponding author: nasreengul78@gmail.com
}

Received November 19, 2018; Revised December 28, 2018; Accepted January 22, 2019

\begin{abstract}
This paper examined the impact of culture on pedagogy in the tribal area of Dera Ghazi Khan (Pakistan). All the teachers working in the female schools of tribal area Dera Ghazi Khan (Pakistan) at primary level, all the female students studying in these schools and all the parents of these students constituted the population of the study. Stratified random sampling technique was used in this study. This study adopted the observational schedule and interview technique instruments. Data were collected from the lessons of 10 teachers, 90 students and 10 parents through stratified random sampling technique. These instruments were validated by five experts in the field of education. For the reliability, a pretesting of these instruments was made three times. The results indicated that culture had a great impact on pedagogy and especially language difference affects greatly the learning process. This study also recommended: local teachers should be appointed in this area, teachers who do not belong to this area should be taught spoken language course of this area, teachers should be regular in schools and some financial aid should be given to the female students of this area.
\end{abstract}

Keywords: teacher, classroom, culture, pedagogy, tribal areas

Cite This Article: Muhammad Tanveer Afzal, and Khalida Nasreen, "An Analysis of the Impact of Culture on Pedagogy in the Tribal Area of Dera Ghazi Khan (Pakistan)." American Journal of Educational Research, vol. 7, no. 1 (2019): 84-92. doi: 10.12691/education-7-1-13.

\section{Introduction}

Education changes the behavior of the individual and enlightens his mind and heart. To change the heart and mind of millions of people is not a simple task and only schools can perform this task. Some schools can perform this task and some cannot. It is a fact that only those schools perform well which have good teachers, effective instruction and provision of good instruction to every child according to his/her need.

Barber and Mourshed (2007) have stated that best schools are those that have best teachers [1]. One of the most important aspects of schools are teachers that are able to create an academically as well as socially, culturally, psychologically or spiritually environment that will help to meet the needs and well-being of the students [2].

But the question is what teachers do and how he/she develops his/her instruction, how he/she chooses to interact with his/her students, structures the classroom and delivers the content. So the teachers should not have a lot of knowledge about the subject matter and curriculum as Tharp, 1999; Tharp et al, 2003 have stated that the teacher should not only be expert in the content and curriculum, to appreciate the different types of standards, to know about the assessment and to organize the lessons but also be able to engage students. It is possible through pedagogy- the science of teaching that a competent teacher combines these elements together. The method through which a teacher interacts with the students and develops instruction are the most important aspects that help a child to learn. (Cited by Entz, 2007) [3]. But in reality in any school system, pedagogical techniques i.e. teaching methods are not just adopted by the decisions of teacher. As Alexander (2001) has also stated that pedagogical strategies are not just developed by the decisions of teacher but also by school values and organization, by local authority, national policy and political control, by culture and history [4].

It is considered that classrooms are complex environments. In a classroom, students come from different classes, backgrounds and especially from culture. All of these students have different lifestyles, different IQ levels, different languages, different social values, different customs and traditions. There will not be possible effective learning if the teacher has no knowledge about the background and culture of the students in these classrooms and schools. This can impact the effectiveness of the learning if the teacher is not aware about the cultural background of the students within the classroom and school [5]. So it is challenge for the teacher to know which pedagogy will help the students to learn most effectively.

In all the teacher education programs of Pakistan, teachers are taught some sort of pedagogies which are designed for the homogenous culture. In these teacher education programs, It is never discussed what the 
teachers should do in the classrooms with their students of different cultures i.e. which type of pedagogy will be suitable for urban areas, rural and tribal areas. Today, there are many gaps in education- achievement gaps, funding gaps and school readiness; but still there is also another gap that has never been studied: the cultural gap between students and teachers [6]. This situation is not only in Pakistan but also in western countries. The principles of many.....teacher education programs are based on homogenous set of western cultural values even though this that their participants/students come from a large number of different cultural backgrounds [7]. The present study is also conducted about culture and pedagogy in Pakistan. It will analyze the impact of culture on pedagogy in the tribal area i.e. tribal area of Dera Ghazi khan in Pakistan.

In the entire world, tribal areas are those areas which are considered backward and uncivilized. These areas have different culture i.e. different language, different geographical location, and different way of life, social values, customs and traditions. The same situation is in the tribal areas of Pakistan. The present study is conducted in the tribal area of D.G.Khan. Tribal area of Dera Ghazi Khan is situated in the province Punjab (Pakistan). Its culture is totally different from the urban areas of Dera Ghazi Khan. I.e. different language, difficult geography, social values, customs and traditions. Most of the teachers who are working in this area belong to urban areas. These teachers have different culture i.e. different language, social values, cognitive thoughts built upon their own society. So the present study is conducted in the tribal area of girls 'schools at primary level to see this when a teacher from urban areas come to teach there, how much his teaching i.e. pedagogy is affected by the culture of this area. The present study is designed for this purpose to find the impact of culture on pedagogy in the female schools of this area at primary level.

The objective of the study was to analyze the impact of culture on pedagogy in the tribal area of D.G.Khan at primary level. The term culture and pedagogy have also been studied.

\section{Review of Related Literature}

\subsection{Definition of Culture}

Spencer-oatey defines culture as a set of basic concepts and values towards life, beliefs, policies, procedures and behavioral habits that are shared by a group of people and that affect each members' behavior and how he/she interprets the behavior of other people [8]. Adiam and Arivia in "Relations between Religion and Culture in Southeast Asia” (2009) have quoted Samovar and Porter (1994) who says "Culture refers to the accumulated deposit of knowledge, experience, beliefs, values, attitudes, hierarchies, religion, notions of time, concepts of the universe and material objects and possessions acquired by a group of people in the course of generations through individual and group striving [9]. So culture is the characteristic of a particular group of people having particular ideas, values, and religion, social behaviors, and language, cognitive thoughts built upon their own social habits, customs and traditions. There is not possible to define culture in a comprehensive way but the researcher has tried to interpret it.

\subsection{Elements of Culture}

Steven E. B (2010) has also worked on culture and described its elements. These elements are as follows: symbols, language, norms, rituals, values and artifacts [10].

\subsection{Pedagogy}

According to Mariam Webster dictionary 2018, pedagogy is the art, science or profession of teaching [11]. Each teacher has a vast number of pedagogical techniques but it is not possible that he/she will be able to get a positive student outcome.

The present study is about culture and pedagogy. Jerome Bruner (1996), "Culture shapes the mind.......it provides us with the toolkit by which we construct not only our worlds but our every conception of ourselves and our powers" [12]. Culture has a great impact on pedagogy. If a teacher adopts such teaching methods which are not appropriate for the culture of his/her classroom, there will not be possible effective learning. So the teacher should adopt that pedagogy which has the elements of culture. CREDE have examined the process of teaching. This research gives importance to the quality of education for all students especially for those at risk for educational failure because of language or cultural barriers, race, geographical location or poverty [13].

\subsection{CREDE Principles for Effective Pedagogy}

CREDE research have described the five principles for effective teaching [13]

1. Joint productive activity

Teachers and students working together on some project or activity

2. Language Development

3. Contextualization

Connecting school life to students 'lives

4. Challenging activities

5. Instructional conversation

The present study was about culture and pedagogy. It was to analyze the impact of culture on pedagogy in the tribal area of D.G.Khan (Pakistan). At first this study discussed those researches about culture and pedagogy which have been done in past.

Culture and pedagogy: International comparisons in primary education

This is the most prominent research work about culture and pedagogy and it was done by Robin Alexander in 2001. This research won the outstanding book award of American Educational Research Association in 2002. This research was of international level and it was conducted in five countries i.e. England, France, India, Russia and the United states. The aim of this book was to describe the link between culture and pedagogy. This research described primary education in terms of ideas about culture and pedagogy. This study revealed this truth that 
pedagogy is such a theme which is neglected by most of the educational thinkers and policy makers but it is most important as, at practical level, it relates to the culture, structure and policy in which it is not just situated but fixed in it. Alexander (2001) suggests that while 'pedagogy is a window on the culture of which it is a part and the tensions related to that culture and contradictions as well as its publicly declared policies and purposes' (p.4) [4]

In this research, there were selected 30 schools (only 6 schools from each country) and 36 lessons were selected for this study. This research was mixed method i.e. both qualitative and quantitative techniques were used. Observational schedule, video cameras, interview techniques, Photographs were used to collect the data. Conclusion was also given. "What we do in our classroom with and to our children is culturally specific. Except perhaps for the "ubiquitous escaping of pedagogical stream. "shh......sh" heard in four out of five countries.... so there are some universals in teaching then' (Alexander, 2001, p.382) [4]

The present study was also about culture and pedagogy and it was conducted in the same manner. Alexander 'research was of international level but the present study was on a small scale. The present study was conducted in one tribal area of Pakistan i.e. the tribal area of D.G.Khan. Tribal area of D.G.Khan comes in the province Punjab (Pakistan) and has a particular language, customs, and difficult geography i.e. hilly area, unpaved roads on hills, lack of transport, good food, clean water, good clothes, education and especially female education. The culture of Tribal area of D, Khan is quite different from the urban areas of D.G.Khan. In this area, most of the teachers who are working belong to urban area and have a different culture i.e. different language, ideas, social values and customs. So the present study was conducted in this area to analyze the impact of culture on pedagogy in the female schools at primary level. In the present study, there were randomly selected 10 female schools for the study at primary level. 10 lessons were selected for the present research in these schools. In these 10 lessons, 7 lessons were selected of those teachers who belonged to another culture i.e. different language, social values, ideas, customs and traditions and 3 lessons were selected of those teachers who belonged to this area. Grades 3 of students were selected and these teachers were also teaching the students of grade 3 in these schools. In this area, there is lack of education especially female education. In these schools, the number of female students at grade 4 and 5 was less. Students who were in Grade 1 and 2 were not able to be interviewed or observed deeply. So grade 3 of students was selected for this study. The present study also used observational schedule and interview technique to collect data. In the end, this study concluded that culture especially language difference affects greatly the teaching methods. It is expected that this study will be helpful to prove this that culture has a great impact on pedagogy.

\section{Methodology}

This section describes the methods and procedures of the study.

\subsection{Design of the Study}

The present study was a mixed method research in which both qualitative and quantitative approaches were used. Qualitative approaches involve the collection of narrative data. Quantitative approaches involve the collection of narrative data. The objective of the study was to analyze the impact of culture on pedagogy. To achieve this objective, data were collected through observational schedule and interview technique. Data of observation was in numbers. Data of interview was narrative. So it was the need of the research that a mixed method research i.e. both qualitative and quantitative approaches should be used.

\subsection{Population}

The population of this study consisted of all the female teachers of tribal area at primary level, the students of these teachers and the parents of the students of these schools. The population of study was divided into three groups:

\section{Population-1}

Population -1 was all the teachers working in the female primary schools of tribal area of D.G.Khan. There were working 378 teachers in these schools. So population -1 was 378 teachers.

\section{Population-2}

Population-2 was all the female students studying in the primary schools of tribal area of D.G.Khan. There were 98 female schools at primary level. There were studying 6500 students in these schools. So population-2 consisted of 6500 students.

\section{Population-3}

Population-3 was all the parents of these students. There were 6500 students. Therefore, third population was 6500 parents.

\subsection{Sampling Technique}

The population of the study was divided in to three strata i.e. three subgroups. So the stratified random sampling technique was used for this purpose.

\subsubsection{Sample}

There were 98 female schools at primary level in tribal area. All the names of the schools were written on the paper slips. These slips were folded and mixed in a small box. One of the teachers was asked to pick up only ten paper slips. So these ten schools were selected as a sample of study. Alexander's research was conducted in five countries and he selected only 30 schools i.e. 0nly 6 schools from each country for his international research work and 36 lessons. Alexander selected theses schools in which there was varied culture. The researcher selected 10 schools for the present study and in each school one lesson was observed for study. So the researcher selected 10 lessons for the study.

In these ten schools, mixed teachers were working i.e. same culture/different culture. In 7 schools, 7 lessons were observed of that teacher who belonged to different culture 
and in 3 schools, 3 lessons were observed of that teacher who belonged to tribal area.

So the sample was drawn in the following way:

Lessons $=10$

Teachers $=10$

Students $=90$

Parents from the selected schools $=10$ (In this area, women are not allowed to take part in such activity i.e. interview. So the father of female students was selected for interview and only those people were involved in these processes who were agreed for interview.

\subsection{Instruments of the Study}

The instruments used in this study were observational schedule and interview technique. These instruments were developed in the context and background of tribal area which was the need of the study. The same instruments were also developed by Alexander (2001) in the western context.

\subsection{Validity and Reliability of the Instruments}

These instruments were validated by five experts in the field of education to see this whether these instruments are achieving that objective or not for which these were developed. Necessary amendments were made in them after their suggestions. For reliability, a pretesting of these instruments was made and one lesson was observed for three times. Alexander (2001) in his five nations study had also observed his lessons for three times. In the same way, a pretesting of interview was also made. The results of pretesting were similar. A coefficient of reliability was not determined here because it is a fact that ground realities do not require reliability because after one or two weeks teachers or students were not being changed that could affect the results of study. But the researcher used numeric data of teachers, students, schools and pretesting of these instruments and validated from the experts for the trustworthiness of this study.

\section{Data Analysis}

Data of observation was analyzed by using a statistical method i.e. percentage. Data of interview was narrative in nature and it was interpreted by the researcher.

\subsection{Results}

\subsubsection{Analysis of Observation Data}

The researcher interpreted the geographical location of this area in words and other results of the components of observational schedule were tabulated and analyzed by a statistical technique i.e. percentage.

Geographical location

At first, the researcher observed the geographical location of this area. The geographical location of this area was difficult i.e. hilly area, dangerous tracks on hills, lack of transport, lack of food, water, electricity and education.

Table 1 shows the physical environment of the class during observing the lesson. It shows that facility of the room was available to the $90 \%$ of the classes during observing the lesson. The facility of the chair and table was available to the $80 \%$ of the classes during observing the lesson. It also shows that facility of textbooks and inkpots was available to the $60 \%$ of the classes during the lesson. The facility of charts related to culture was not available in any class during observing the lesson. This table shows that the facility of blackboards and chalks was available to $60 \%$ of the classes during observing the lesson.

Table 1. Physical environment in the class

\begin{tabular}{|c|c|c|c|}
\hline $\begin{array}{c}\text { Total lessons } \\
\text { observed }\end{array}$ & A class has & $\begin{array}{c}\text { Number of } \\
\text { lessons }\end{array}$ & $\%$ \\
\hline 10 & Room & 9 & 90 \\
\hline & Chair & 8 & 80 \\
\hline & Table & 8 & 80 \\
\hline & Textbook and inkpots & 6 & 60 \\
\hline & $\begin{array}{c}\text { Charts related to } \\
\text { students culture }\end{array}$ & 0 & 0 \\
\hline & Blackboard and chalks & 6 & 60 \\
\hline
\end{tabular}

Table 2. Teacher status who was presenting the lesson

\begin{tabular}{|c|c|c|c|}
\hline $\begin{array}{c}\text { Total lessons } \\
\text { observed }\end{array}$ & Teacher belongingness & $\begin{array}{c}\text { Number of } \\
\text { lessons }\end{array}$ & $\%$ \\
\hline 10 & Same culture & 3 & 30 \\
\hline & Different culture & 7 & 70 \\
\hline & $\begin{array}{c}\text { Have some knowledge of } \\
\text { student culture and background }\end{array}$ & 3 & 30 \\
\hline & \multicolumn{2}{|r}{} \\
\hline
\end{tabular}

Table 2 shows the teacher status who was presenting the lesson to the class. It shows that $30 \%$ of teachers belong to tribal area and $70 \%$ teachers do not belong to tribal area. It also shows that only 30\% teachers were aware about the students 'culture and background and $70 \%$ teachers were unaware about the students 'culture and background.

Table 3. Social interaction during the lesson

\begin{tabular}{|c|c|c|c|}
\hline $\begin{array}{c}\text { Total lessons } \\
\text { observed }\end{array}$ & $\begin{array}{c}\text { Relationship of teacher with } \\
\text { the students }\end{array}$ & $\begin{array}{c}\text { Number of } \\
\text { lessons }\end{array}$ & $\%$ \\
\hline 10 & Positive & 3 & 30 \\
\hline & Negative & 0 & 0 \\
\hline & Neutral & 7 & 70 \\
\hline
\end{tabular}

Table 3 tells about the social environment during the lesson. It tells that the relationship of $30 \%$ of teachers was positive with the students and $70 \%$ of the relationship of teachers with the students was neutral It also tells that there was no teacher whose relationship was negative with the students.

Table 4. Teaching method during the lesson

\begin{tabular}{|c|c|c|c|}
\hline $\begin{array}{c}\text { Total lessons } \\
\text { observed }\end{array}$ & $\begin{array}{c}\text { Teachers 'method of } \\
\text { teaching }\end{array}$ & $\begin{array}{c}\text { Number of } \\
\text { lessons }\end{array}$ & $\%$ \\
\hline 10 & Lecture method & 7 & 70 \\
\hline & Discussion method & 3 & 30 \\
\hline & $\begin{array}{c}\text { Group activities and } \\
\text { practices }\end{array}$ & 0 & 0 \\
\hline
\end{tabular}


Table 4 indicates the teaching method. It indicates that $70 \%$ of the teachers were using lecture method and $30 \%$ teachers were using discussion method. This table also indicates that there was no teacher who was using group activities and practices teaching methods during the lessons.

Table 5. Language of teacher during the lesson

\begin{tabular}{|c|c|c|c|}
\hline $\begin{array}{c}\text { Total lessons } \\
\text { observed }\end{array}$ & $\begin{array}{c}\text { A teacher was using } \\
\text { the language }\end{array}$ & $\begin{array}{c}\text { Number of } \\
\text { lessons }\end{array}$ & $\%$ \\
\hline 10 & Urdu & 1 & 10 \\
\hline & Balouchi & 3 & 30 \\
\hline & Suraiki & 6 & 60 \\
\hline & Other & 0 & 0 \\
\hline
\end{tabular}

Table 5 tells about the language of teacher which she was using during the lesson. It tells that $10 \%$ teachers were presenting their lessons in Urdu language and 30\% teachers were using balouchi language. It also tells that $60 \%$ teachers were using surailki language. This table also tells that there was no teacher who using other language i.e. English during presenting the lessons.

Table 6. Content of the textbooks

\begin{tabular}{|c|c|c|c|}
\hline $\begin{array}{c}\text { Total lessons } \\
\text { observed }\end{array}$ & $\begin{array}{c}\text { Content of the } \\
\text { textbooks }\end{array}$ & $\begin{array}{c}\text { Number of } \\
\text { lessons }\end{array}$ & $\%$ \\
\hline 10 & Related to culture & 0 & 0 \\
\hline & Urdu version & 0 & 0 \\
\hline & English version & 0 & 0 \\
\hline & Mixed Urdu/English & 10 & 10 \\
\hline
\end{tabular}

Table 6 gives description about the content of the textbooks. It describes that the content was not related to culture and it was not totally in Urdu and English language. It tells that the contents of the textbooks were mixed method i.e. in both Urdu and English language.

Table 7. Assessment of students

\begin{tabular}{|c|c|c|c|}
\hline $\begin{array}{c}\text { Total lessons } \\
\text { observed }\end{array}$ & $\begin{array}{c}\text { A teacher was assessing } \\
\text { the work of students }\end{array}$ & $\begin{array}{c}\text { Number of } \\
\text { lessons }\end{array}$ & $\%$ \\
\hline 10 & orally & 8 & 80 \\
\hline & written & 2 & 20 \\
\hline & orally/written & 0 & 0 \\
\hline
\end{tabular}

Table 7 tells about how the teacher was assessing the work of students at the beginning and end of the lesson. It shows that $80 \%$ of teachers were assessing the work of students orally and only $20 \%$ of teachers were assessing the work of students through written skill. This table also shows that there was no teacher who was assessing the work of students through both methods i.e. oral and written method.

\subsubsection{Analysis of Interview Data for Teachers}

An interview was conducted with these teachers. Most of the teachers working in these schools were ESE (science-math) and they did not belong to tribal area. They were selected according to the open merit policy of the government. Majority of the teachers were not regular to schools because of long distance from their house to school, difficult geography and lack of transport. They stated that most of the students are of shy nature and they do not interact with them freely. The students treat with them like strangers. They cannot involve their students in discussing the subject matter so they have to use the lecture method. Most of the teachers stated that their language is suraiki/Urdu and the language of tribal area is balochi. The main problem which they face during teaching is the language difference because of which they cannot build good relationship with their students.

\subsubsection{Analysis of Interview Data for Students}

All of the students were in grade 3. Most of the students stated that they do not come to school regular because of absence of teachers, customs and traditions in which there is not given priority to female education, ignorance of parents and neutral attitude of the teachers etc. Most of the students stated that their language is balochi and the language of their teacher is surailki/balochi. So they cannot ask questions about their studies and give answers frequently to their teacher. Majority of the students stated that their teaches are of urban areas. They have different language, dresses and viewpoints and they do not give importance to their students because of which they cannot come close to their teacher.

\subsubsection{Analysis of Interview Data for Parents}

An interview was conducted with the parents of these students. In this area, women are not allowed to take part in such activities as interview etc. so the interview was conducted with the father of the students. Most of the parents were poor and their occupation was only farming and grazing cattle. Some people were also in army, to have a hotel and maulvi. Most of the parents do not send their children to school because of absence of teachers, gender preference, poverty and traditions. Majority of the parents stated that the teacher belongs to urban area and their language, dresses, shoes and a way of speaking is quite different from their children. Their children feel hesitation to communicate with them and to take part in classroom activities. These teachers do not come to school regular and do not give importance to the education of their children. Most of the parents stated their children gains nothing from the lessons of their teachers because she presents her lesson in another la another language and she does not relate it to studenst' culture. The teacher completes the responsibility of spending his time in the classroom and has nothing to do with the education of children. The govt. should give funds our children, make regular these teachers or appoint local teachers in this area.

\section{Conclusion and Discussion}

In the education system, it is considered that teacher must be competent and have a lot of knowledge about his/her subject matter. The high quality of an education system depends mainly upon the quality of teaching. Barber and Mourshed (2007) have also said this that quality of an education system cannot exceed the quality of its teachers [1]. A teacher can get positive student 
outcome if its teaching methods are according to the culture of the class. Pedagogy is such a term towards which educational thinkers give little attention in all worlds. All the teacher education programs are based on theoretical concepts about education and teaching and are developed for the homogeneous culture in the entire world especially in Pakistan. It is never taught to the teachers what they should do in the classrooms with their students i.e. in respect of culture, language and individual differences. It is a fact that a teacher plays an important role in the classroom. A teacher serves as a light in the classroom. Classrooms are often considered as diverse and complex places i.e. in respect of culture, language and individual differences. In a classroom, there are different students i.e. bright, dull, shy nature, have different culture i.e. different language, dresses, social values, cognitive thoughts built upon their own society. Classroom complexity exists not only among students but it also exists between teacher and students because of language and cultural differences. Effective teaching occurs only when a teacher recognizes all these language and cultural differences and adjusts his/ her teaching according to the individual differences and students interests.

The present study was also designed for such purpose and it was to analyze the impact of culture on pedagogy in the tribal area of D.G.Khan. This study showed that this area has difficult geography i.e. hilly area, unpaved and winding roads on hills. This area is deprived of basic facilities. There is lack of transport and education especially female education. This area has its own culture i.e. different language, social values, customs and traditions about female and her education. This study showed that physical facilities were available to a great extent in all these classrooms .Most of the teachers in this area did not belong to tribal area and they were little aware about the culture of this area.

There is always meaningful learning when there is a positive social interaction between teacher and students. But in the present study teacher showed neutral attitude to students. Teachers were presenting their lessons in another language without caring for it whether students are benefitting from the learning process or not. The more experienced person use language, activities and emotional excitement to promote the Childs' persona, linguistic and cultural construction of the ideas, skills and process that are the basis of learning [14]. When teacher is only involved in learning process and there is no interaction between teacher and students, it is impossible that the students' cognitive abilities will be raised. Brown (2013) has also cited vygotsky (1996) who says that when children take part in guided interactions with more experienced class fellows and teachers, they more rapidly get the "mental abilities" required by their culture [14]. This study showed that content of the textbooks was in Urdu and English language. It is acknowledged that the textbooks are designed for the whole nation but if these textbooks should be described / taught by a teacher to different culture of students in their own language and according to their own society, the students will understand these books in a proper way and they can also discuss this knowledge with their teachers. In this way their thinking powers will also be developed. Alexander's research shows that teacher's meaningful classroom dialogue encourages the process of sharing knowledge and skills [14]. This research also showed that most of the teachers were assessing the work of students orally. The researcher assessed that the students' progress was very slow because of less interaction between teacher and students.

This research showed that teachers who were teaching in this area were qualified people. Most of the teachers belong to urban areas and the distance from their house to school was also very long. They are unaware about the customs and traditions of this area and especially language. The main problem which they face during teaching is the language difference. This study also told about those teachers who were aware about the language and customs of this area, there was good relationship between teacher and students. But these teachers were less in number. This study also analyzed the viewpoint of students and parents. The students described that the social environment of class is not good because teacher talks in another language and they do not take interest in their language, customs and traditions and especially in their studies. The research also described the parents 'viewpoints that teachers are not regular to schools and their language, dresses and thinking is quite different from this area. They have no sympathy for their children and Govt. should give funds to our children for studying.

As a whole this study concluded that culture has a great impact on pedagogy. If a teacher is highly educated as there are in tribal area i.e. MSc Mathematics, Physics, English, M. Phil and they also know about the modern teaching methods. But when these teachers have to enter in such a classroom which has a different culture i.e. different language, customs, social values and cognitive thoughts built upon their own society, it is impossible that in such environment the effective teaching will be occurred. Effective teaching occurs only when it is relevant to students 'lives and culture. CREDE research is very helpful for all students especially for those who are in a crisis of cultural or language barriers [13]. It is also a fact that geographical location of this area is difficult. There is a lack of transport because of which teachers cannot come to school regular. It can also come to mind if the teachers would be regular to schools, perhaps there can also be a chance the teacher-pupil relationship could also be strong and meaningful learning be possible. But all of it is impossible without effective communication i.e. to talk with them. Talk is the main source for instruction in schools [14]. If the teacher is unaware about the culture and especially language of the students, he /she will not be able to talk with the students and to teach them in their own language. Language plays a vital role in building relationship with teacher-pupil. Through language, anyone can also express its own thoughts and culture. More importantly, language plays a vital role in human learning. Culture and pedagogy is a detailed examination of teacher-pupil discourse- for language is at once the most powerful tool for human learning and the expression of culture and identity (Alexander, 2009, p.2) [15]. Effective pedagogy occurs only at that time when a teacher is aware about the language and cultural differences of the students. In this period, CREDE principles are very effective for 
teaching because it stresses on positive social interaction between teachers and students, development of language between teacher and students and in the content areas, connecting the curriculum to the students 'lives [13].

Last days, the researcher attended a workshop PEELI. This workshop was supported by British Council. The aim of this workshop was that the teachers should speak English with their students in the classrooms and their teaching method should be Activity Based Learning English at primary level. The researcher was in that cluster of teachers who belonged to tribal area. But the researcher was astonished that there was raised no question that there is another culture especially language in this area and there will not be possible to apply such teaching methods in English language. The researcher considers perhaps it is the destiny of the tribal female students that they will not only remain backward in the world but also specially in the field of education.

\section{Recommendations}

This study recommended the following steps:

1. Local teachers should be appointed in this area. It should not be considered that they are less educated i.e. Matric, F.A etc.

2. Teachers who belong to another culture and are not able to speak the language of this area should be given the training of spoken language courses of this area.

3. Teachers should create positive relationship with the students i.e.to shake hands with the students, to ask about their family members and weather etc.

4. The Govt. should made regular the teachers of this area

5. Transport facility should also be given the teachers of this area.

6. The Govt. should give some financial aid to the female children of this area.

\section{References}

[1] Barber, M., \& Mourshed, M. How the worlds 'best- performing school systems come out on top, 2007, London: A survey of McKinsey \& company.

[2] J. Reyhmer, W. S. Gilbert \& L. Lockard (Eds.), Honoring Our Heritage: Culturally Appropriate Approaches for Teaching Indigenous Students, 2011, (pp 1-9). Flagstaff, AZ: Northern Arizona University.

[3] Entz, S, Why Pedagogy Matters: The Importance of Teaching In A Standards-Based Environment, 2007, Hawaii Community College. Forum on Public Policy.

[4] Alexander, R.J, Culture and Pedagogy: International comparisons in primary Education, Oxford, Blackwell, 2001.

[5] Tankard, G.M, The Importance of Acknowledging Cultural orientation To Guide Pedagogical Practices, 2015, Culture \& Pedagogy. Vol 1.

[6] Culture in the classroom/teaching tolerance. (n.d). Retrieved from https://www.tolerance.org/culture-classroom.

[7] Badger, R., \& MacDonald. M. N. Culture, Language, Pedagogy: the place of culture in language teaching education. (2007). Pedagogy, Culture \& Society, 15 (2), 215-227.

[8] Spencer-oately, H, What is culture? A compilation of quotations, 2012, Global PAD core concepts. Retrieved from https://www.warwick.ac.uk/globalpadintercultural.

[9] Adian, G.D., \& Arivia, G, Relations between Religions and Cultures in Southeast Asia, 2009. Retrieved from https:/books.Google? ISBN= 1565182502.

[10] Steven E. B, Sociology: Understanding \& Changing The Social World, 2010, Brief Edition. Boston, MA: Flat world.

[11] Marriam Webster Dictionary, Pedagogy/Definition of Pedagogy, 2018. Retrieved from https://www.marriam-webster.com/dictionary pedagogy.

[12] Smith, M. K, Jerome's Bruner \& the process of education, 2002 , the encyclopedia of informal education. Retrieved from https://Infed.org/mobi/Jerome-brunerand-the-process-of-education.

[13] Tharp, R G, The CREDE five standards for effective pedagogy, 2008, University of Hawaii at Manoa. College of education. Retrieved from manoa. Hawaii. Edu/coe/credenational/effectiveteaching/.

[14] Brown, T, T2 Classroom Dialogue, 2013, Rutledge. Taylor and Francis (2014).

[15] Alexander, R.J, Towards a comparative pedagogy: International Handbook of Comparative Education, Cowen, R. \& Kazamias, A.M.(ed), 2009

\section{Appendix}

\section{Instruments of the study}

The instruments used in this study were observational schedule and interview technique. These instruments were developed in the context and background of tribal area which was the need of the study. The same instruments were also developed by Alexander (2001) in the western context.

\section{Development of instruments}

The researcher developed the instruments in the following way:

\section{Observational Schedule}

The present study is to analyze the impact of culture on pedagogy in the tribal area of D.G.Khan. It is only in female schools of tribal area during the lesson presentation of teacher at primary level. Therefore, this observational schedule is being used by the observer to analyze the impact of culture on pedagogy. The following components are used by the observer in each lesson.

Components 1) Geographical location

2) Physical environment

3) Teacher status

4) Social environment

5) Teaching method 
6) Language of teacher during the lesson

7) Content of the textbooks

8) Assessment of students

\begin{tabular}{|c|c|}
\hline Constructs & Statements \\
\hline 1. Physical environment & 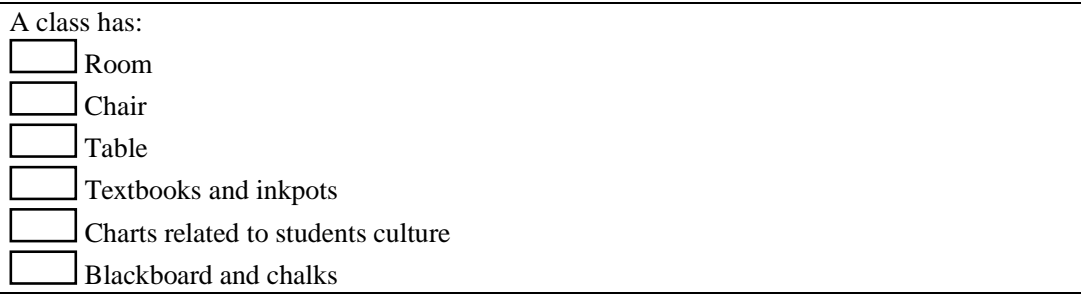 \\
\hline 2. Teacher status & $\begin{array}{l}\text { A teacher belongs to: } \\
\begin{array}{|l}\text { Same culture } \\
\text { Different culture } \\
\\
\end{array} \text { Have some knowledge of Students culture and Background }\end{array}$ \\
\hline 3. Social environment & 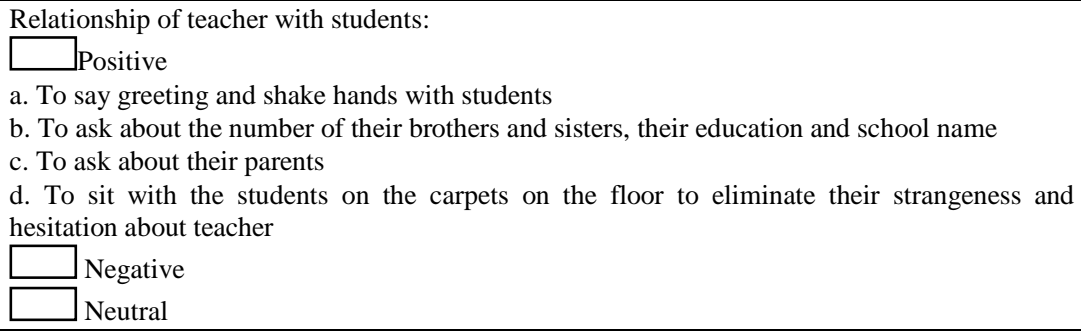 \\
\hline 4. Teaching method during the lesson & $\begin{array}{l}\text { A teacher was using method of teaching: } \\
\text { Lecture method } \\
\text { (A teacher was individually Involved in learning Process and was and was giving Information } \\
\text { orally } \\
\text { Discussion method } \\
\text { (Teacher was discussing the lesson with the students and was involving the students in the } \\
\text { Learning process) } \\
\text { Group activities } \\
\text { Practice }\end{array}$ \\
\hline 5. Language of teacher during the lesson & 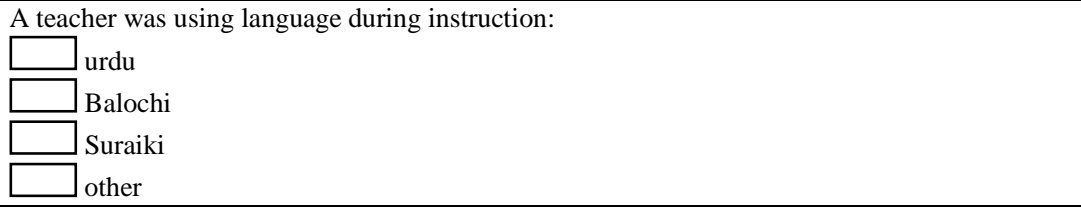 \\
\hline 6. Content of the textbooks & 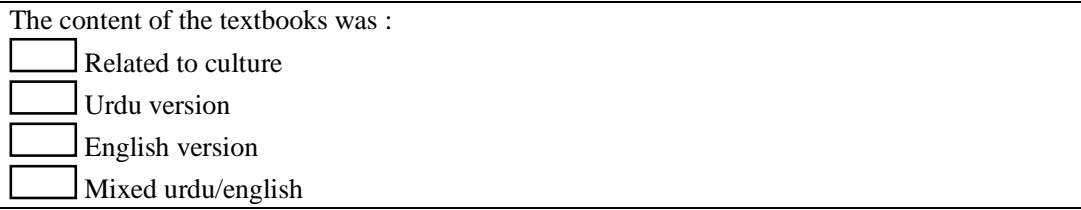 \\
\hline 7. Assessment of students & $\begin{array}{l}\text { A teacher was assessing the work of students: } \\
\begin{array}{|l}\text { orally } \\
\text { written }\end{array}\end{array}$ \\
\hline
\end{tabular}

\section{Interview Protocol}

An interview scheduled was also developed for teachers, students and parents of these students. This is a English version of interview. Actually, interview was conducted for teachers in urdu language. For students and parents, interview was conducted in balochi language.

\section{Interview Protocol for teachers}

An interview was developed for teachers. This was English version of interview. Actually interview was conducted in urdu language. The following questions were asked from teachers:

Q.1 what is your present status in this school?

Q.2 Do you belong to tribal area?

Q.3 If not, do you have some awareness about the culture and background of this area?

Q.4 Do all the teachers come to school regular in this area?

Q.5 If not, what are the causes responsible for it?

Q.6 which type of students does you face in your class room? 
Q.7 which teaching method do you use in the presentation of your lesson?

Q.8 what problems do you face in the presentation of your lesson?

\section{Interview protocol for students}

An interview was also developed for students. This is English version of interview. Actually was conducted in balochi language. The following questions were asked from students:

Q.1 what is your grade in the school?

Q.2 Do your teacher come to school regular in this area?

Q.3 If not, why

Q.4 In which language your teacher presents his lesson?

Q.5 Does your teacher involve you during the presentation of his lesson?

Q.6 what problems do you face during your classroom activities?

\section{Interview protocol for parents}

An interview was developed for parents. This is English version of interview. Actually interview was developed in balochi language. The following questions were asked from parents:

Q.1 what is your occupation? Do you have all the necessities of life?

Q.2 Do you send your female children to school regular?

Q.3 If not, what are the reasons for it?

Q.4 what problems your children face during the classroom activities?

Q.5 what do you think from the authorities of education department?

(C) The Author(s) 2019. This article is an open access article distributed under the terms and conditions of the Creative Commons Attribution (CC BY) license (http://creativecommons.org/licenses/by/4.0/). 